Sains Malaysiana 50(12)(2021): 3493-3503

http://doi.org/10.17576/jsm-2021-5012-03

\title{
Determination of the Heavy Metal Contents and the Benefit/Cost Analysis of Hypericum salsugineum in the Vicinity of Salt Lake
}

(Penentuan Kandungan Logam Berat dan Analisis Faedah/Kos Hypericum salsugineum di Sekitar Salt Lake)

\author{
AYNur DEMIR*, GÖKÇEN BAYSAl FurTANA, MEHTAP TEKŞEn \& RUKIYE TIPIRDAMAZ
}

\section{ABSTRACT}

In this study, Hypericum salsugineum, an endemic halophytic plant growing around Salt Lake, was analyzed to determine the heavy metals (chromium, lead, copper, zinc and nickel) on it and on the soil it grew. The phytoremediation potential of $\mathrm{H}$. salsugineum was evaluated. In addition, the benefit cost $(B / C)$ analysis was performed for its potential use in phytoremediation. The plant and soil samples were collected from Eskil and Cihanbeyli between May and September in 2016. A total of 300 soil and plant samples were analysed for heavy metal content. Statistical and standard benefit/ cost analyses were performed for assessment. The capacity of accumulating the aforementioned heavy metals was found to be high in $\mathrm{H}$. salsugineum. It was found that $\mathrm{Ni}$ and $\mathrm{Pb}$ ratio exceeded optimum values in its habitat, and $\mathrm{H}$. salsugineum accumulated available $\mathrm{Ni}$ and $\mathrm{Pb}$. When the plant was evaluated in terms of benefit/cost, B/C ratio was greater than 1 during the useful life of the study. This conclusion increases the ecological and economical values of $\mathrm{H}$. Salsugineum, effecting its potential use in phytoremediation.

Keywords: Economic value analysis; halophyte; Hypericum salsugineum; phytoremediation; Salt Lake

ABSTRAK

Dalam kajian ini, Hypericum salsugineum, sejenis tumbuhan halofit endemikyang tumbuh di sekitar Tasik Garam telah dianalisis untuk menentukan kandungan logam berat (kromium, plumbum, kuprum, zink dan nikel) padanya dan pada tanah tempat ia tumbuh. Potensi fitopemulihan H. salsugineum juga telah dinilai. Selain itu, analisis nisbah faedah/kos $(F / K)$ telah dilakukan untuk potensi kegunaan dalam fitopemulihan. Sampel tumbuhan dan tanah telah dikumpul daripada Eskil dan Cihanbeyli antara Mei dan September 2016. Sejumlah 300 sampel-sampel tanah dan tumbuhan telah dianalisis untuk kandungan logam berat. Analisis statistik dan analisis Piawai Faedah/Kos telah dilakukan sebagai penaksiran. Kapasiti pengumpulan logam berat tersebut telah diperoleh dalam jumlah yang tinggi di dalam $\mathrm{H}$. salsugineum. Nisbah $\mathrm{Ni}$ dan $\mathrm{Pb}$ didapati telah melebihi nilai optimum dalam habitat dan kandungan yang dikumpul daripada $\mathrm{H}$. salsugineum. Apabila tumbuhan ini dinilai berdasarkan faedah/kos, nisbah (F/K) telah menunjukkan nilai yang lebih besar daripada 1 sepanjang kajian dijalankan. Rumusan ini menambah nilai ekologi dan ekonomi H. salsugineum, yang seterusnya memberi kesan kepada potensinya untuk digunakan dalam fitopemulihan.

Kata kunci: Analisis nilai ekonomi; fitopemulihan; halofit; Hypericum salsugineum; Salt Lake

\section{INTRODUCTION}

Heavy metal pollution is regarded as the primary factor in degrading ecological balance as it is proved to be a serious problem both in Turkey and in the world. It is known as a significant problem when heavy metals exceed optimum values which are regarded as both esential or nonesential for plants (Benavides et al. 2005; Niess 1999). Similarly, when heavy metals are found in soil above the regular percentage, soil structure deteriorates, and product yield and quality decrease. They all cause serious problems for humans and other living beings (Blaylock \& Huang 2000; Long et al. 2002).

Instead of costly and demanding remediation techniques and the traditional engineering methods used to clear areas polluted with heavy metals, phytoremediation has recently been introduced as an environmentally friendly and low-cost reclamation method (Arshad et al. 2008; Glass 2000; Salt et al. 1995; Shi et al. 2009). This method of collecting heavy metals from soil by using plants aims to transform them into a more manageable and 
transportable form. To do so, hyper-accumulator plants are used in phytoremediation. These plants collect between 50 and 500 times more heavy metals from soil into their branches and stems (Clemens 2006). Compared to different reclamation methods, phytoremediation has many advantages such as rather low-cost, aesthetic satisfaction, easy-use, and short term application (Aybar et al. 2015).

Some metals taken by plants are disintegrated through the enzymes in the plant body, and their chemical forms are altered. Most of the metals which do not go through any disintegration are accumulated in plant leaves and stems. They are disposed after harvesting. It has been determined that some plants are highly effective in accumulating heavy metals from soil and tolerant against heavy metal toxicity (Cunningham \& Ow 1996). There are approximately 450 hyper-accumulator plants which make up $0.2 \%$ of all flowering plants (Baker \& Brooks 1989; Brooks 1998; Ellis \& Salt 2003; Milner \& Kochian 2008; Reeves 2006). Some families such as Brassicaceae, Euphorbiaceae, Asteraceae, Lamiaceae and Scrophulariaceae are known as hyper collectors (Baker \& Brooks 1989).

In recent years, stress factors such as salinity, high temperature, cold and drought, which are caused by global climate change, have increased the efforts to investigate the phytoremediation possibilities of halophytic plants.

There are reasons to use halophytes such as Hypericum salsugineum N. Robson \& Hub.-Mor. for phytoremediation. Halophytic plants tolerate environmental stresses such as salinity and heavy metals. These plants have common physiological mechanisms to environmental stresses. Some halophytes use salt glands and trichomes on their leaf surface to remove excess salt ions. At the same time, they work to remove heavy metals. Halophytic plants can accumulate heavy metals, so they are ideal species for phytostabilization or phytoextraction of heavy metal contaminated salty soils. They are naturally present in habitats characterized by dense toxic ions such as sodium and chloride (Manousaki \& Kalogerakis 2011). In recent years, researchers favour halophytic species such as Atriplex halimus L. (Lef'evre et al. 2009; Manousaki \& Kalogerakis 2009), Atriplex nummularia Lindl. (Jordan et al. 2002), Mesembryanthemum crystallinum L. (Ghnaya et al. 2007, 2005), Sesuvium portulacastrum (L.) L. (Ghnaya et al. 2007, 2005), Tamarix smyrnensis Bunge and Tamarix parviflora DC. (Manousaki et al. 2008), Halimione portulacoides (L.) Aellen (Lutts \& Lef'evre 2015), Limoniastrum monopetalum (L.) Boiss. (Manousaki et al. 2013), Juncus acutus L. (Lutts \& Lef'evre 2015), and salt marsh plants (Castro et al. 2009; Manousaki \& Kalogerakis 2011).

Hypericum salsugineum (halophytic centaury, St John's-wort) is an endemic plant species among halophytic plants. The genus Hypericum has approximately 400 species worldwide in various sections, and these plants have been used in traditional medicine for a long time. This genus is represented by 98 taxa, 45 of which are endemic (Bingöl et al. 2010). The conservation status of H. salsugineum is CR (Critically Endangered) according to International Union for Conservation of Nature (IUCN 2019). It is also listed in the plant preservation list included in the Supplementary List 1 of Bern Convention (Adıgüzel et al. 2005; Davis 1967).

The phytoremediation studies on Hypericaceae family, which became a symbol of salt stress, are quite new. In the study conducted by Shafaghat et al. (2012), it was determined that Hypericum scabrum L. can be used as an absorbent for the removal of $93.9 \% \mathrm{~Pb}$ and $72.2 \% \mathrm{Cu}$ ions from aqueous solutions, and stated that H. scabrum has the potential to be used against $\mathrm{Pb}$ and $\mathrm{Cu}$ in phytoremediation applications. It has also been shown that Hypericum perforatum L. can be used in phytoremediation, especially as a $\mathrm{Pb}$ accumulator (Ayan et al. 2006; Radanović et al. 2002). Therefore, it is important to investigate the potential use of other Hypericum species in phytoremediation.

In this study, the possibilities of using $H$. salsugineum, which is an endemic halophytic plant growing around Salt Lake, in phytoremediation were investigated, and its economic value was determined. The phytoremediation potential of $H$. salsugineum was evaluated by performing analysis on the plant and the soil that it grows for heavy metals such as chromium, lead, nickel, zinc and copper. In addition, benefit-cost analysis of the use of the plant in phytoremediation was performed.

\section{MATERIALS AND METHODS}

\section{PRESENTATION OF RESEARCH AREA}

Salt Lake is located within the borders of Aksaray, Konya, and Ankara in Central Anatolia Region (Figure 1). It is a terrestrial evaporation environment that enlives a seasonal transition type between terrestrial salt pans (Salzpfannen) and salty lakes (Salz Seen) (Demir 2014). The length of the lake is $85 \mathrm{~km}$ and the width is $45 \mathrm{~km}$. Peçeneközü and Melendiz streams in the east and Insu stream in the west reach Salt Lake which has a supply basin of approximately 16,000 km² (Demir 2014). Salt Lake is surrounded by salty marshes. 


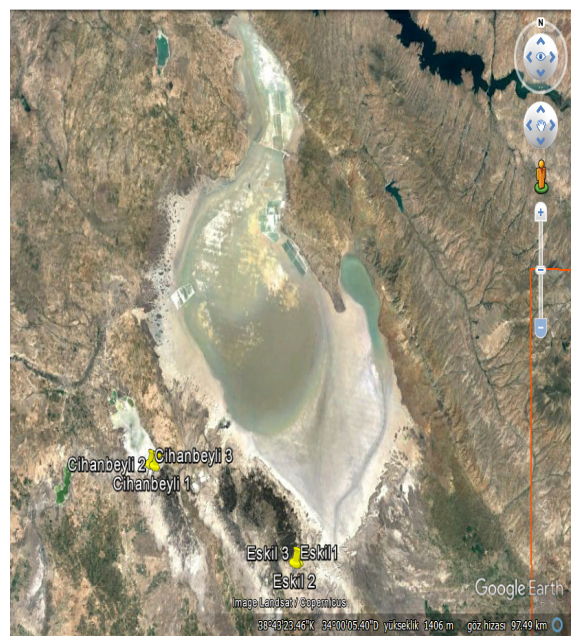

FIGURE 1. Aerial view of Salt Lake. The coordinates were measured with Global Positioning System (GPS)

These marshes are halophytic vegetation zones that have varying physiognomic and floristic compositions on the arid areas around the lake (Baysal Furtana et al. 2013). In 2001, Salt Lake was declared as a Special Protection Area (SPA), including the surrounding water beds and some of the important steppe areas. The salty marshes in the region are the richest areas in terms of endemism (Baysal Furtana et al. 2013). Salt Lake, which is mostly less than half a meter deep, becomes a bird's paradise with winter rains. However, the surface of the lake is covered with salt crystals which transforms the ground into an endless lowland with the evaporation of lake water in summer (Basak 2003; Demir 2014). Additionally, the salinity level varies in seasons, and the lake water becomes extremely salty with a salt content of $32.4 \%$ and a density of $1.225 \mathrm{gr} / \mathrm{cm}^{3}$ (Baysal Furtana et al. 2013). The amount of average annual rainfall in the region is $250 \mathrm{~mm}$. The period with the least rain and the highest temperature is from June to September. The drought season that starts at the end of June takes 3-4 months. The lake area is under the impact of a semi-arid and cold Mediterranean climate. $78 \%$ of the soil in the lake basin is characterized as salty and alkaline. As a result, Salt Lake and the surrounding area are a suitable habitat for a large number of halophytic plants and ecotypes of some glycophytes (Baysal Furtana et al. 2013).

\section{COLLECTING SOIL AND PLANT SAMPLES}

The study areas included Eskil, Aksaray (Figure 2) and Cihanbeyli, Konya (Figure 3) which are the natural habitats of $H$. salsugineum. Field studies were conducted five times with regular intervals based on the vegetation period (flowering and fruiting) between May and September 2016.

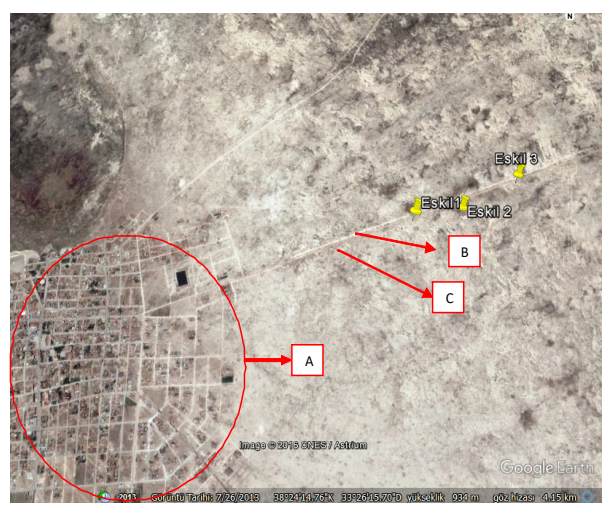

FIGURE 2. The location of Eskil. A. Eskil (Residential district), B.

Road and C. Sewage Canal (approximate distance to the road 3-4 m) 


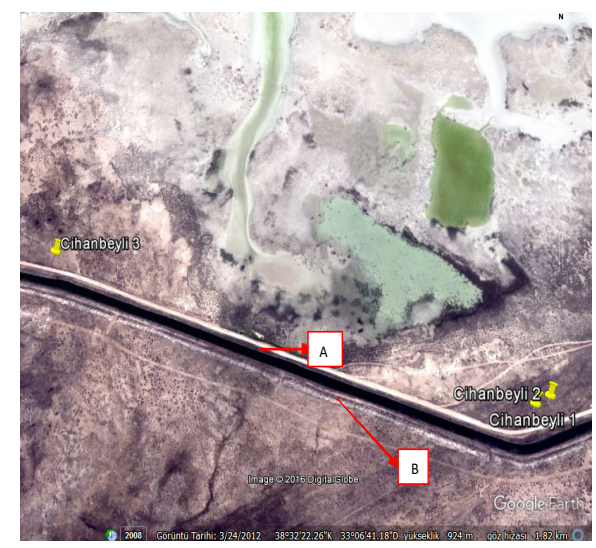

FIGURE 3. The location of Cihanbeyli. A. Road and B. Sewage Canal

A plant sample was collected from each station (root, stem and leaves in May; root, stem, leaves and flowers in June, July and August; root, stem, leaves, flowers, and fruits in September). As a result of the field studies, 30 fresh plant materials were obtained from both stations. Before the analysis, the plant material was purified from substances such as dust, soil and plant parts that could affect the analyses. Thirty soil samples from Eskil and Cihanbeyli plant collection stations were taken, placed in bags, labelled, and delivered to the laboratory for analyses. Each sample was $1.5 \mathrm{~kg}$ each and collected between 20 and $40 \mathrm{~cm}$ under the soil surface which is the level of plant roots.

During the field studies, soil and plant samples were gathered regularly from the selected stations. The coordinates of plants were defined by Global Positioning System (GPS). The photos of collected plant samples were taken in their natural habitats. The plants were transformed into herbarium material, and they are currently stored in the Herbarium of Aksaray University (AKSU) in the Scientific and Technological Research and Application Centre of Aksaray University (ASUBTAM).

The soil and plant samples were gathered 5 times from 6 different locations (in the two main stations of Eskil and Cihanbeyli) in 5 months. A total of 300 soil and plant samples were analysed for heavy metals content (chromium, lead, copper, zinc and nickel).

\section{PREPARATION AND ANALYSIS OF SOIL AND PLANT SAMPLES}

The soil samples were ground to a size of $20 \mu \mathrm{m}$ in a ballbearing tungsten carbide vane. Five $g$ of the powdered sample was mixed homogeneously with $1 \mathrm{~g}$ of Micropulver
Wachs C. The wax and sample mixture was then pelletized with a Die Attacher at a pressure of $13 \mathrm{~kg} / \mathrm{N}$. The obtained press pellet was placed on WD-XRF (Wavelength Dispersive X-ray Fluorescence) apparatus, and heavy metals were determined. The plant leaves that weighed approximately $0.2 \mathrm{~g}$ were placed in a microwave, and the microwave dissolving process was analysed with ICP-MS (Inductively Coupled Plasma Mass Spectrometry).

\section{CALCULATION OF BIOCONCENTRATION FACTOR}

The Bioconcentration Factor (BCF) is the metal uptake capacity of a plant from soil to plant tissue which is calculated using analyzed metals $(\mathrm{Pb}, \mathrm{Zn}, \mathrm{Cu}, \mathrm{Cr}$ and $\mathrm{Ni}$ ) in plant and soil (Ghosh \& Singh 2005).

$\mathrm{BCF}=$ metal concentration in the plant tissue/metal concentration in soil

\section{STATISTICAL AND ECONOMICAL ANALYSIS}

The laboratory findings were evaluated based on ANOVA statistical methods. SPSS 23 statistical program was used to calculate standard deviations and means. In this research, $\alpha$ was taken to be 0.05 . Analysis results were considered as significant if calculated p-values were $\leq 0.05$. For the comparison of the means, ANOVA and Post Hoc Duncan test were used (Duman et al. 2007).

An economical value analysis of the plant for its use in removing heavy metals from soil was conducted after investigating the data acquired with the statistical and laboratory analyses during the study period by using Mishan's method of 'Standard Benefit/Cost Analysis' (Mishan 1972). In this research, the heavy metal 
accumulation amount of $H$. salsugineum was determined as a total benefit. Under laboratory conditions, the chemical consumable amounts which are used in the heavy metal analyss were considered as total variable costs. The total $\mathrm{B} / \mathrm{C}$ value was evaluated by the following formula in the equations (1) and (2). The fixed costs were ignored in this study.

$$
\begin{aligned}
& B / C=\frac{\sum_{t=1}^{T} \frac{T B t}{(1+i)^{t}}}{\sum_{t=0}^{T} \frac{T C t}{(1+i)^{t}}} \\
& B / C=\frac{\sum T B_{t}^{d}}{\sum T C_{t}^{d}} \geq 1
\end{aligned}
$$

where $B$ is benefits; $T B t$ is the total annual benefits; $C$ is cost; TCt is the total annual cost; TBtd is discounted total annual benefits; TCtd is the discounted total annual cost; $t$ is the time, $I$ is discount rate (Demir 2014; Mishan 1972).

\section{RESULTS AND DISCUSSION}

The heavy metal amounts of the soil samples taken from Eskil and Cihanbeyli are shown in Table 1. The maximum average values of $\mathrm{Pb}, \mathrm{Zn}, \mathrm{Cu}, \mathrm{Cr}$ and $\mathrm{Ni}$ in the soil from Eskil were $105.6( \pm 14.5), 18.82( \pm 3.54)$, $60.3( \pm 8.87), 20.04( \pm 1.62)$ and $158.1 \mathrm{mg} \cdot \mathrm{kg}^{-1}( \pm 19.56)$, respectively. The maximum average values of $\mathrm{Pb}, \mathrm{Zn}$, $\mathrm{Cu}, \mathrm{Cr}$ and $\mathrm{Ni}$ in the soil from Cihanbeyli were 93.0 $( \pm 58.3), 13.65( \pm 5.88), 46( \pm 8.85), 17.72( \pm 1.99)$, and 116 $\mathrm{mg} . \mathrm{kg}^{-1}( \pm 27.70)$, respectively. When these average values are examined, each region showed a linear increase in itself in terms of $\mathrm{Pb}, \mathrm{Zn}, \mathrm{Cu}, \mathrm{Cr}$ and $\mathrm{Ni}$ in the soil between May and July. It is seen that there was a linear decrease in the heavy metal content of the soil in August and September. However, $\mathrm{Zn}, \mathrm{Cu}, \mathrm{Ni}$ and $\mathrm{Cr}$ contents in the soil samples taken from Eskil were higher than Cihanbeyli, but $\mathrm{Pb}$ content was lower with no significant difference. These findings are consistent with literature. According to Tuğ and Duman (2010), the rates of $\mathrm{Pb}$ and $\mathrm{Ni}$ are especially quite high in Cihanbeyli and Aksaray.

TABLE 1 . The average heavy metals $\left(\mathrm{Cu}, \mathrm{Zn}, \mathrm{Pb}, \mathrm{Cr}\right.$, and $\mathrm{Ni}$ ) contents $\left(\mathrm{mg}_{\mathrm{kg}} \mathrm{kg}^{-1}\right), \mathrm{pH}$ and electrical conductivity (EC)

\begin{tabular}{|c|c|c|c|c|c|c|}
\hline & & May & June & July & August & September \\
\hline \multirow[t]{2}{*}{ Soil pH } & Eskil & 7.75 & 7.75 & 7.87 & 7.64 & 7.91 \\
\hline & Cihanbeyli & 8.44 & 8.25 & 7.98 & 7.99 & 7.86 \\
\hline \multirow[t]{2}{*}{ Soil EC } & Eskil & 23.70 & 11.34 & 27.74 & 51.45 & 35.25 \\
\hline & Cihanbeyli & 12.57 & 6.76 & 30.60 & 32.18 & 69.95 \\
\hline \multirow[t]{3}{*}{ Soil $\mathrm{Cu}$} & Eskil & $44.53 \pm 15.91$ & $47.3 \pm 10.38$ & $60.3 \pm 8.87$ & $35.27 \pm 11.83$ & $21.5 \pm 6.03$ \\
\hline & Cihanbeyli & $38.73 \pm 10.43$ & $40.23 \pm 11.96$ & $46 \pm 8.85$ & $36.97 \pm 24.50$ & $33.9 \pm 15.86$ \\
\hline & Optimum* & 25 & & & & \\
\hline \multirow[t]{3}{*}{ Soil Zn } & Eskil & $13.69 \pm 1.59$ & $18.6 \pm 3.03$ & $18.82 \pm 3.54$ & $15.75 \pm 3.73$ & $13.31 \pm 2.95$ \\
\hline & Cihanbeyli & $10.3 \pm 1.23$ & $12.82 \pm 1.57$ & $13.65 \pm 5.88$ & $12.64 \pm 2.01$ & $11.62 \pm 0.85$ \\
\hline & Optimum & 150 & & & & \\
\hline \multirow[t]{3}{*}{ Soil Pb } & Eskil & $39.8 \pm 4.3$ & $44.3 \pm 26.3$ & $64.6 \pm 28.7$ & $71.1 \pm 17.8$ & $105.5 \pm 14.5$ \\
\hline & Cihanbeyli & $58.5 \pm 32.7$ & $64.3 \pm 28.5$ & $77.2 \pm 36.4$ & $77.6 \pm 23.6$ & $93.0 \pm 58.3$ \\
\hline & Optimum & 50 & & & & \\
\hline \multirow[t]{3}{*}{ Soil Cr } & Eskil & $13.71 \pm 2.56$ & $13.89 \pm 2.43$ & $17.61 \pm 3.42$ & $20.04 \pm 1.62$ & $15.45 \pm 4.86$ \\
\hline & Cihanbeyli & $11.31 \pm 2.21$ & $11.35 \pm 1.62$ & $16.94 \pm 5.19$ & $17.72 \pm 1.99$ & $13.25 \pm 1.59$ \\
\hline & Optimum & 30 & & & & \\
\hline \multirow[t]{3}{*}{ Soil Ni } & Eskil & $92.3 \pm 23.46$ & $98.4 \pm 40.06$ & $136.7 \pm 39.20$ & $158.1 \pm 19.56$ & $113.9 \pm 18.99$ \\
\hline & Cihanbeyli & $88.2 \pm 12.22$ & $98.6 \pm 13.67$ & $106.5 \pm 30.85$ & $116 \pm 27.70$ & $104.6 \pm 3.29$ \\
\hline & Optimum & 10 & & & & \\
\hline
\end{tabular}
values in the soil of Salt Lake. *optimum value reference is FAO/WHO (Srivastava et al. 2017) 
According to the analyses, the heaviest metal accumulation was seen in July and August. When the annual precipitation and temperature averages of the region are evaluated, the period between July and August has the lowest the precipitation and the highest temperature (Anonymous 2010), and the evaporation is the highest. Heavy metals and minerals become mobile and are washed into deeper levels of soil, but they turn back to upper layers through the evaporation in summer due to increasing temperature. Therefore, heavy metal concentrations in the soil increase in summer (Tuğ \& Duman 2010). The highest level of heavy metals was observed in summer when the evaporation was high. The growing impact of salinity on heavy metal mobility in the soil is determined based on the amount of electrolytes, and it also depends on the total amount of heavy metals and on the kind of salt stimulating salinization (Lutts \& Lef'evre 2015). The chloride salts and the sulfate salt have three main mechanisms regulating metal mobility. These are complexification with sulfates, complexification with chlorides and competition with $\mathrm{Ca}$ and/or $\mathrm{Mg}$ for sorption sites (Acosta et al. 2011; Lutts \& Lef'evre 2015). The main mechanisms in the regulation the mobility of heavy metals in soil are competition with $\mathrm{Ca}^{2+}$ for absorption areas and complexification with sulfate for $\mathrm{Cu}$ (Lutts \& Lef'evre 2015).

In accordance with the field studies, the main sources of heavy metal pollution in the region are domestic and industrial wastes, sewage, septic waste, pesticide, agricultural activities, air pollution, traffic and oil, volcanic dust and gases, use of artificial fertilizers and animal grazing. The pollution load of the sampling area in Eskil can be explained by its proximity to the garbage collection and residential area of the district and the presence of an open sewage system parallel to the sampling area (Figure 2). The pollution load in Cihanbeyli can be explained with the main drainage channel carrying the industrial waste from Konya, the sewerage system passing through this area, the presence of vehicle traffic, animal grazing, and intensive agriculture activities (Figure 3). Because both regions are located within a volcanic area, it is also thought to be a significant effect on heavy metal accumulation. Therefore, the sources of heavy metals are volcanic activity, wind-blown dust particles, and desert dusts (Nagajyoti et al. 2010; Srivastava et al. 2017). It was found that $\mathrm{Ni}$ and $\mathrm{Pb}$ pollution was higher in the soil samples from Eskil and Cihanbeyli regions.

Heavy metals $(\mathrm{Pb}, \mathrm{Zn}, \mathrm{Cu}, \mathrm{Cr}$, and $\mathrm{Ni}$ ) contents in H. salsugineum plants are presented in Table 2. The maximum average values of metal concentrations were
$2.54( \pm 1.78), 8.02( \pm 1.02), 6.88( \pm 1.90)), 0.92( \pm 0.47)$ and $3.4( \pm 2.62) \mu \mathrm{g} / \mathrm{g}$ in the plant samples from Eskil and $2.65( \pm 1.93), 5.54( \pm 0.94), 7.3( \pm 1.10), 0.58( \pm 0.25)$ and $3.57( \pm 0.37) \mu \mathrm{g} / \mathrm{g}$ in the plant samples from Cihanbeyli for $\mathrm{Pb}, \mathrm{Zn}, \mathrm{Cu}, \mathrm{Cr}$ and $\mathrm{Ni}$, respectively. According to the observed results, $H$. salsugineum accumulated $\mathrm{Pb}$ and $\mathrm{Ni}$ in both locations. $\mathrm{Pb}$ and $\mathrm{Ni}$ are unstable and easily converted to oxides, carbonates and sulphates (Lone et al. 2006; Wuana \& Okieimen 2011). Heavy metal incorporation into oxalate crystals has also been correlate in $\mathrm{Cd}, \mathrm{Cu}, \mathrm{Pb}$ and $\mathrm{Ni}$ (Choi et al. 2001; Lintern et al. 2013; Oosten \& Maggio 2015; Yang et al. 2000). This is how it is accumulated on the leaves and removed from the salt glands. The least period in which heavy metal accumulated in the plant samples from both localities was in May, and the highest period was in August. It can be explained by the beginning of the vegetation period of the plant in May. In this period, excessive rainfall and humidity might cause the plant to take less heavy metals from the soil. In August, the plant begins to flower and completes the vegetative period. In this period, the amount of precipitation decreases, and evaporation in the soil increases with increasing temperature. Since heavy metals reach the surface of the soil, where the plant can reach with its roots, more heavy metal can be accumulated in the plant through osmotic regeneration and picked up in the salt glands of the leaves. The heavy metals accumulated by the salt mechanism are removed from the plant with flowers and foliage in September.

Moreover, it is thought that EC (electrical conductivity) and $\mathrm{pH}$ values of the soil in saline areas also play a significant role in the heavy metal accumulation by the plant. The findings from the current study conclude that $\mathrm{pH}$ and $\mathrm{EC}$ values in the soil did not change significantly depending on the season. In terms of $\mathrm{pH}$, Cihanbeyli region, however, has been found to be slightly alkaline ( $\mathrm{pH}$ 7.64-8.44) compared to Eskil. Alkaline soils immobilize heavy metals at high $\mathrm{pH}$, and the soil protects itself against heavy metal effects (Abosede \& Mokin 2017; Chibuike \& Obiora 2014; Srivastava et al. 2017; Tuğ 2006). However, this study showed that the increase in the use of fertilizer in agricultural activities may increase EC value of the soil and lead to heavy metal accumulation, especially in saline soils (Chibuike \& Obiora 2014; Srivastava et al. 2017; Tuğ 2006).

According to the results of correlation analysis, heavy metals in the soil and the plant were significantly correlated with each other, with a positive relation between plant and soil (Table 3). Among the analysed heavy metals, positive correlations were obtained for $\mathrm{Cr}$ 
and $\mathrm{Zn}$ with $\mathrm{Ni}$ in the soil; $\mathrm{Cr}, \mathrm{Cu}, \mathrm{Zn}$ with $\mathrm{Cr}$ in the soil; $\mathrm{Cr}, \mathrm{Cu}$, and $\mathrm{Zn}$ with $\mathrm{Ni}$ in the soil; $\mathrm{Cr}$ and $\mathrm{Zn}$ with $\mathrm{Cu}$ in the plant; $\mathrm{Cu}$ and $\mathrm{Zn}$ with $\mathrm{Ni}$ in the plant; and $\mathrm{Cu}$ and $\mathrm{Zn}$ in the plant (Table 3). These results lead to the conclusion that the sources of pollution in the soil are widespread, and $H$. salsugineum can accumulate heavy metals.

TABLE 2. The average heavy metals $(\mathrm{Cu}, \mathrm{Zn}, \mathrm{Pb}, \mathrm{Cr}$ and $\mathrm{Ni})$ contents $\left(\mathrm{mg} . \mathrm{g}^{-1}\right)$ in $H$. salsugineum. *Optimum value reference is FAO/WHO (Srivastava et al. 2017)

\begin{tabular}{ccccccc}
\hline & & May & June & July & August & September \\
\hline Plant $\mathrm{Cu}$ & Eskil & $3.02 \pm 2.19$ & $3.61 \pm 1.76$ & $4.98 \pm 1.39$ & $6.88 \pm 1.90$ & $5.75 \pm 1.13$ \\
& Cihanbeyli & $1.64 \pm 0.26$ & $1.48 \pm 0.38$ & $2.4 \pm 0.24$ & $7.3 \pm 1.10$ & $5.45 \pm 2.17$ \\
& Optimum* & 10 & & & & \\
\multirow{3}{*}{ Plant $\mathrm{Zn}$} & Eskil & $3.79 \pm 0.91$ & $3.25 \pm 1.41$ & $5.33 \pm 2.14$ & $8.02 \pm 1.02$ & $6.17 \pm 2.73$ \\
& Cihanbeyli & $0.642 \pm 0.40$ & $2.68 \pm 1.27$ & $2.57 \pm 1.06$ & $5.54 \pm 0.94$ & $3.23 \pm 1.21$ \\
& Optimum & 50 & & & & $2.02 \pm 1.36$ \\
Plant Pb & Eskil & $1.31 \pm 0.46$ & $1.59 \pm 0.54$ & $1.7 \pm 0.80$ & $2.54 \pm 1.78$ & $1.6 \pm 1.10$ \\
& Cihanbeyli & $1.38 \pm 0.10$ & $1.58 \pm 0.14$ & $1.52 \pm 0.61$ & $2.65 \pm 1.93$ & $0.68 \pm 0.03$ \\
& Optimum & 1 & & & & $0.54 \pm 0.14$ \\
Plant $\mathrm{Cr}$ & Eskil & $0.37 \pm 0.15$ & $0.33 \pm 0.04$ & $0.55 \pm 0.16$ & $0.92 \pm 0.47$ & $0.58 \pm 0.25$ \\
& Cihanbeyli & $0.18 \pm 0.12$ & $0.22 \pm 0.16$ & $0.29 \pm 0.08$ & & $2.34 \pm 1.15$ \\
& Optimum & 1.5 & & & & $2.76 \pm 1.49$
\end{tabular}

TABLE 3. Correlation coefficients between heavy metal content in the soil and plant materials

\begin{tabular}{|c|c|c|c|c|c|c|c|c|c|c|c|}
\hline & Time & Soil Cr & Soil Ni & Soil $\mathrm{Cu}$ & Soil Zn & Soil $\mathrm{Pb}$ & Plant $\mathrm{Cr}$ & Plant Ni & Plant $\mathrm{Cu}$ & $\begin{array}{l}\text { Plant } \\
\text { Zn }\end{array}$ & $\begin{array}{c}\text { Plant } \\
\mathrm{Pb}\end{array}$ \\
\hline \multicolumn{12}{|l|}{ Time } \\
\hline Soil Cr & $.380 *$ & & & & & & & & & & \\
\hline Soil Ni & $.372 *$ & $.619 * *$ & & & & & & & & & \\
\hline Soil Cu & -.306 & -.022 & -.011 & & & & & & & & \\
\hline Soil Zn & -.022 & .357 & $.573 * *$ & .172 & & & & & & & \\
\hline Soil Pb & $.543 * *$ & .225 & .274 & .081 & -.083 & & & & & & \\
\hline Plant Cr & $.595^{* *}$ & $.522 * *$ & $.563 * *$ & -.255 & .077 & .117 & & & & & \\
\hline Plant Ni & $.543 * *$ & .149 & .307 & -.259 & .224 & .238 & .151 & & & & \\
\hline Plant $\mathrm{Cu}$ & $.674 * *$ & $.502 * *$ & $.521 * *$ & -.243 & .274 & .107 & $.663 * *$ & $.542 * *$ & & & \\
\hline Plant Zn & $.529 * *$ & $.605^{* *}$ & $.512 * *$ & -.222 & .273 & .162 & $.695^{* *}$ & $.397 *$ & $.571 * *$ & & \\
\hline Plant $\mathrm{Pb}$ & .272 & .269 & .157 & .214 & -.025 & $.413^{*}$ & .156 & .318 & .181 & .359 & \\
\hline
\end{tabular}

** Correlation is significant at the 0.01 level (2-tailed), * Correlation is significant at the 0.05 level (2-tailed) 
Bioconcentration Factor (BCF) of the studied heavy metals increased in a time-dependent manner. BCF values of heavy metals varied between $0.061 \pm 0.026$ and $0.272 \pm 0.025,0.169 \pm 0.049$ and $0.518 \pm 0.060,0.018 \pm 0011$ and $0.041 \pm 0.015,0.024 \pm 0.001$ and $0.047 \pm 0.013$, and
$0.011 \pm 0.003$ and $0.021 \pm 0.014$ in the samples from Eskil; $0.037 \pm 0.002$ and $0.277 \pm 0.193,0.060 \pm 0.032$ and $0.438 \pm 0.005,0.016 \pm 0.002$ and $0.031 \pm 0.016,0.015 \pm 0.008$ and $0.040 \pm 0.006$, and $0.013 \pm 0.001-0.031 \pm 0.005$ in the samples from Cihanbeyli for $\mathrm{Cu}, \mathrm{Zn}, \mathrm{Pb}, \mathrm{Cr}$ and $\mathrm{Ni}$, respectively (Table 4).

TABLE 4. The Bioconcentration Factor (BCF) of the studied heavy metals

\begin{tabular}{|c|c|c|c|c|c|c|}
\hline & & May & June & July & August & September \\
\hline \multirow[t]{2}{*}{$\mathrm{Cu}$} & Eskil & $0.061 \pm 0.026$ & $0.073 \pm 0.022$ & $0.082 \pm 0.011$ & $0.198 \pm 0.013$ & $0.272 \pm 0.025$ \\
\hline & Cihanbeyli & $0.043 \pm 0.005$ & $0.037 \pm 0.002$ & $0.053 \pm 0.005$ & $0.277 \pm 0.193$ & $0.165 \pm 0.015$ \\
\hline \multirow[t]{2}{*}{$\mathrm{Zn}$} & Eskil & $0.274 \pm 0.035$ & $0.169 \pm 0.049$ & $0.275 \pm 0.063$ & $0.518 \pm 0.060$ & $0.448 \pm 0.108$ \\
\hline & Cihanbeyli & $0.060 \pm 0.032$ & $0.203 \pm 0.075$ & $0.189 \pm 0.004$ & $0.438 \pm 0.005$ & $0.274 \pm 0.084$ \\
\hline \multirow[t]{2}{*}{$\mathrm{Pb}$} & Eskil & $0.032 \pm 0.008$ & $0.041 \pm 0.015$ & $0.026 \pm 0.001$ & $0.033 \pm 0.018$ & $0.018 \pm 0.011$ \\
\hline & Cihanbeyli & $0.030 \pm 0.018$ & $0.028 \pm 0.011$ & $0.026 \pm 0.002$ & $0.031 \pm 0.016$ & $0.016 \pm 0.002$ \\
\hline \multirow[t]{2}{*}{$\mathrm{Cr}$} & Eskil & $0.026 \pm 0.006$ & $0.024 \pm 0.001$ & $0.031 \pm 0.004$ & $0.045 \pm 0.020$ & $0.047 \pm 0.013$ \\
\hline & Cihanbeyli & $0.015 \pm 0.008$ & $0.018 \pm 0.012$ & $0.017 \pm 0.001$ & $0.032 \pm 0.011$ & $0.040 \pm 0.006$ \\
\hline \multirow[t]{2}{*}{$\mathrm{Ni}$} & Eskil & $0.011 \pm 0.003$ & $0.014 \pm 0.002$ & $0.013 \pm 0.001$ & $0.021 \pm 0.014$ & $0.020 \pm 0.007$ \\
\hline & Cihanbeyli & $0.014 \pm 0.001$ & $0.015 \pm 0.002$ & $0.013 \pm 0.001$ & $0.031 \pm 0.005$ & $0.026 \pm 0.013$ \\
\hline
\end{tabular}

In this regard, $H$. salsugineum showed a statistically strong potential to remove $\mathrm{Pb}$ and $\mathrm{Ni}$ from the soil. The benefit value of $\mathrm{Pb}$ removal of the plant was $2.54 \mathrm{mg} \cdot \mathrm{g}^{-1}$ for Eskil region and $2.65 \mathrm{mg} . \mathrm{g}^{-1}$ for Cihanbeyli region. The benefit value of Ni removal was $3.4 \mathrm{mg}^{-\mathrm{g}^{-1}}$ for Eskil region and $3.54 \mathrm{mg}^{-\mathrm{g}^{-1}}$ for Cihanbeyli region. The total cost value of the benefit was $\$ 0.055$. The chemical substances $\left(\mathrm{HNO}_{3}\right.$, $\mathrm{HClO}_{3}$ and $\mathrm{H}_{2} \mathrm{O}_{2}$ ) utilized in the laboratory analyses were used in the calculation of the cost. VAT was not included in the calculations.

In this case, $\mathrm{B} / \mathrm{C}$ ratio for $\mathrm{Pb}$ removal was 46.18 for Eskil and 48.18 for Cihanbeyli. The $\mathrm{B} / \mathrm{C}$ ratio for $\mathrm{Ni}$ removal was 61.81 for Eskil and 64.36 for Cihanbeyli. Since the $\mathrm{B} / \mathrm{C}$ ratio was greater than $1, H$. salsugineum is economically low-cost and can be preferred in phytoremediation practises. The results of this research are in accordance with literature findings. The cost of cleaning of heavy metal contaminated soils via phytoextraction is 5-40 \$/ton (Glass 1999; Lasat 2000). The greatest benefit of phytoremediation is its cost being lower than chemical applications. For example, the cost of clearing contaminated areas of heavy metals in the US by conventional methods is $\$ 7.1$ billion. According to Memon et al. (2001), the total clean-up of contaminated areas that have been identified and characterized in the world was estimated to cost over $\$ 10$ billion using phytoremediation technologies, which would be approximately 1000-fold cheaper than conventional remediation methods. It also provides in-situ improvement instead of moving the pollution to a different area.

\section{CONCLUSION}

The results of this study showed that the potential use of $H$. salsugineum in phytoremediation applications is significantly high. Considering the effects of global climate change, it can be said that this species will be a good accumulator especially for $\mathrm{Pb}$ and $\mathrm{Ni}$. The transportation of metals from the roots to the overground parts of plants and the excretion on the leaf surface increase with salinity. Therefore, halophytes that have better physiological characteristics to overcome environmental stresses present new opportunities for phytoremediation applications. The $\mathrm{B} / \mathrm{C}$ ratio was greater than 1, which support the results above. The benefits of $\mathrm{Pb}$ and $\mathrm{Ni}$ removal are higher in terms of cost. The aesthetic appearance is good, and the application cost is low. These increase the potential use of the plant. 
The local plants which are part of the vegetation have been used in phytoremediation in the surrounding of Salt Lake without disturbing the natural structure of the environment, damaging the vegetation, or creating landscape pollution. In this point of view, this research is the first study to investigate the phytoremediation possibilities of $H$. salsugineum. Therefore, the research has a great importance in terms of its results, and it will provide a great contribution to the literature. Further studies are needed to determine the critic level of each heavy metal and elucidate the accumulation and toxicity level of heavy metals for this plant. Additionally, exploring the potential use of phytoremediation of all the plants in Salt Lake area will be an important step towards the sustainable use of plant diversity and the prevention of environmental problems caused by global climate change in future.

\section{ACKNOWLEDGEMENTS}

This study was funded by BAP (Scientific Research Projects) of Aksaray University (Project no: 2016/054).

\section{REFERENCES}

Abosede, A. \& Mokin, I. 2017. Review on heavy metals contamination in the environment. European Journal of Earth and Environment 4(1): 1-6.

Acosta, J.A., Jansen, B., Kalbitz, K., Faz, A. \& MartínezMartínez, S. 2011. Salinity increases mobility of heavy metals in soils. Chemosphere 85(8): 1318-324.

Adıgüzel, N., Byfield, A., Duman, H. \& Vural, M. 2005. Tuz Gölü ve Stepleri. In Türkiye'nin 122 Önemli Bitki Alanı, edited by Özhatay, N., Byfield, A. \& Atay, S. İstanbul: Türkiye WWF Türkiye (Doğal Hayatı Koruma Vakfi) Yayını. pp. 289-292.

Anonymous. 2010. Salt Lake special environmental protection area habitat monitoring report. T.C. Ministry of Environment and Forestry Special Environmental Protection Agency. https://tvk.csb.gov.tr/tuz-golu-ozel-cevre-koruma-bolgesitur-ile-habitat-koruma-ve-izleme-projesi-proje. Accessed on 15 December 2017.

Arshad, M., Silvestre, J., Pinelli, E., Kallerhoff, J., Kaemmerer, M., Tarigo, A., Shahid, M., Guiresse, M., Pradere, P. \& Dumat, C. 2008. A field study of lead phytoextraction by various scented Pelargonium cultivars. Chemosphere 71(11): 2187-2192.

Ayan, A.K., Kizilkaya, R., Cirak, C. \& Kevseroglu, K. 2006. Heavy metal contents of St. John's Wort (Hypericum perforatum L.) growing in northern Turkey. Journal of Plant Sciences 1(3): 182-186.

Aybar, M., Bilgin, A. \& Sağlam, B. 2015. Removing heavy metals from the soil with phytoremediation. Artvin Çoruh University Natural Disasters Application and Research Center Journal of Natural Hazards and Environment 1(12): 59-65.
Baker, A.J.M. \& Brooks, R.R. 1989. Terrestrial higher plants which hyperaccumulate metallic elements - A review of their distribution. Ecology and Phytochemistry, Biorecovery 1: 81-126.

Basak, E. 2003. Economic and socio-economic valuation of Tuz Gölü specially protected area, Central Anatolia, Turkey. Wageningen University. M.Sc. Thesis (Unpublished).

Baysal Furtana, G., Duman, H. \& Tipırdamaz, R. 2013. Seasonal changes of inorganic and organic osmolyte content in three endemic Limonium species of Lake Tuz (Turkey). Turkish Journal of Botany 37(3): 455-463.

Benavides, M.P., Gallego, S.M. \& Tomaro, M.L. 2005. Cadmium toxicity in plants. Brazilian Journal of Plant Physiology 17(1): 21-34.

Bingöl, Ü., Cosge, B. \& Gürbüz, B. 2010. Hypericum species in the flora of Turkey. Medicinal and Aromatic Plant Science and Biotechnology 5(1): 86-90.

Blaylock, M.J. \& Huang, J.W. 2000. Phytoextraction of metals. In Phytoremediation of Toxic Metals: Using Plants to Clean-up the Environment, edited by Raskin, I. \& Ensley, B.D. New York: Wiley. pp. 53-70.

Brooks, R.R. 1998. General introduction. In Plants that Hyperaccumulate Heavy Metals: Their Role in Phytoremediation, Microbiology, Archaeology, Mineral Exploration and Phytomining, edited by Brooks, R.R. New York: CAB International. pp. 1-14.

Castro, R., Pereira, S., Ana Lima, A., Corticeiro, S., V'alega, M., Pereira, E., Duarte, A. \& Figueira, E. 2009. Accumulation, distribution and cellular partitioning of mercury in several halophytes of a contaminated salt marsh. Chemosphere 76(10): 1348-1355.

Chibuike, U.G. \& Obiora, C.S. 2014. Heavy metal polluted soils: Effect on plants and bioremediation methods. Applied and Environmental Soil Science 2014: 752708.

Choi, Y.E., Harada, E., Wada, M., Tsuboi, H., Morita, Y., Kusano, T. \& Sano, H. 2001. Detoxification of cadmium in tobacco plants: Formation and active secretion of crystals containing cadmium and calcium through trichomes. Planta 213(1): 45-50.

Clemens, S. 2006. Toxic metal accumulation, responses to exposure and mechanisms of tolerance in plants. Biochimie 88(11): 1707-1719

Cunningham, S.D. \& Ow, D.W. 1996. Promises and prospects of phytoremediation. Plant Physiology 110(3): 715-719.

Davis, P.H. 1967. Flora of Turkey and the East Aegean Islands 2. Edinburgh: Edinburgh University Press.

Demir, A. 2014. Recreational use value of Tuz Lake in Turkey. Journal of Food, Agriculture \& Environment 12(2): 10921096.

Duman, F., Aksoy, A. \& Demirezen, D. 2007. Seasonal variability of heavy metals in surface sediment of Lake Sapanca, Turkey. Environmental Monitoring and Assessment 133(13): 277-283.

Ellis, D.R. \& Salt, D.E. 2003. Plants selenium and human health. Current Opinion in Plant Biology 6(3): 273-279. 
Ghnaya, T., Slama, I., Messedi, D., Grignon, C., Ghorbel, M.H. \& Abdelly, C. 2007. Effects of $\mathrm{Cd}^{2+}$ on $\mathrm{K}^{+}, \mathrm{Ca}^{2+}$ and $\mathrm{N}$ uptake in two halophytes Sesuvium portulacastrum and Mesembryanthemum crystallinum: Consequences on growth. Chemosphere 67(1): 72-79.

Ghnaya, T., Nouairi, I., Slama, I., Messedi, D., Grignon, C., Abdelly, C. \& Ghorbel, M.H. 2005. Cadmium effects on growth and mineral nutrition of two halophytes: Sesuvium portulacastrum and Mesembryanthemum crystallinum. Journal of Plant Physiology 162(10): 1133-1140.

Ghosh, M. \& Singh, S.P. 2005. Comparative uptake and phytoextraction study of soil induced chromium by accumulator and high biomass weed species. Applied Ecology and Environmental Research 3(2): 67-79.

Glass, D.J. 1999. Economic potential of phytoremediation. In Phytoremediation of Toxic Metals: Using Plants to Clean Up the Environment, edited by Raskin, I. \& Ensley, B.D. New York: John Wiley \& Sons. pp. 15-31.

Glass, D.J. 2000. The 2000 Phytoremediation Industry. Needham: Glass Associates.

IUCN. 2019. Guidelines for Using the IUCN Red List Categories and Criteria: version 4. Gland: IUCN Standards and Petitions Committee.

Jordan, F.L., Robin-Abbott, M., Maier, R.M. \& Glenn, E.P. 2002. A comparison of chelator-facilitated metal uptake by a halophyte and a glycophyte. Environmental Toxicology Chemistry 21(12): 2698-2704.

Lasat, M.M. 2000. The Use of Plants for the Removal of Toxic Metals from Contaminated Soil. Washington: U.S. Environmental Protection Agency.

Lef'evre, I., Marchal, G., Meerts, P., Corr'eal, E. \& Lutts, S. 2009. Chloride salinity reduces cadmium accumulation by the Mediterranean halophyte species Atriplex halimus L. Environmental Experimental Botany 65(1): 142-152.

Lintern, M., Anand, R., Ryan, C. \& Paterson, D. 2013. Natural gold particles in Eucalyptus leaves and their relevance to exploration for buried gold deposits. Nature Communications 4: 2274.

Lone, M.I., Raza, S.H., Muhammad, S., Naeem, M.A. \& Khalid, M. 2006. Lead content in soil and wheat tissue along roads with different traffic loads in Rawalpindi District. Pakistan Journal of Botany 38(4): 1035-1042.

Long, X.X., Yang, X.E. \& Ni, W.Z. 2002. Current status and perspective on phytoremediation of heavy metal polluted soils. Journal of Applied Ecology 13: 757-762.

Lutts, S. \& Lef'evre, I. 2015. Review: Part of a special issue on halophytes and saline adaptations. How can we take advantage of halophyte properties to cope with heavy metal toxicity in salt-affected areas? Annals of Botany 115(3): 509-528.

Manousaki, E. \& Kalogerakis, N. 2011. Halophytes - An emerging trend in phytoremediation. International Journal of Phytoremediation 13(10): 959-969.

Manousaki, E. \& Kalogerakis, N. 2009. Phytoextraction of $\mathrm{Pb}$ and Cd by the Mediterranean saltbush (Atriplex halimus L.): Metal uptake in relation to salinity. Environmental Science and Pollution Research 16(7): 844-854.
Manousaki, E., Galanaki, K., Papadimitriou, L. \& Kalogerakis, N. 2013. Metal phytoremediation by the halophyte Limoniastrum monopetalum (L.) Boiss.: two contrasting ecotypes. International Journal Phytoremediation 16(7-8): 755-769.

Manousaki, E., Kadukova, J., Papadantonakis, N. \& Kalogerakis, N. 2008. Phytoextraction and phytoexcretion of Cd by Tamarix smyrnensis growing on contaminated non saline and saline soils. Environmental Research 106(3): 326-332.

Memon, A.R., Aktopraklıgil, D., Özdemir, A. \& Vertii, A. 2001. Heavy metal accumulation and detoxification mechanisms in plants. Turkish Journal Botany 25(3): 111-121.

Milner, M.J. \& Kochian, L.V. 2008. Investigating heavy-metal hyperaccumulation using Thlaspi caerulescens as a model system. Annals of Botany 102(1): 3-13.

Mishan, E.J. 1972. The futility of pareto-efficient distributions. The American Economic Review 62(5): 971-976.

Nagajyoti, P.C., Lee, K.D. \& Sreekanth, T.V.M. 2010. Heavy metals, occurrence and toxicity for plants: A review. Environmental Chemistry Letters 8(3): 199-216.

Niess, D.H. 1999. Microbial heavy-metal resistance. Applied Microbiology and Biotechnology 51: 730-750.

Oosten, M.J.V. \& Maggio, A. 2015. Functional biology of halophytes in the phytoremediation of heavy metal contaminated soils. Environmental and Experimental Botany 111: 135-146.

Radanović, D., Antić-Mladenović, S. \& Jakovljević, M. 2002. Influence of some soil characteristics on heavy metal content in Hypericum perforatum L. and Achillea millefolium L. Acta Horticulturae 576: 295-301.

Reeves, R.D. 2006. Hyperaccumulation of trace elements by plants. In Phytoremediation of Metal-Contaminated Soils NATO Science Series: IV: Earth and Environmental Sciences, edited by Morel, J.L., Echevarria, G. \& Goncharova, N. New York: Springer. pp. 1-25.

Salt, D.E., Prince, R.C., Pickering, I.J. \& Raskin, I. 1995. Mechanisms of cadmium mobility and accumulation in Indian Mustard. Plant Physiology 109(4): 1427-1433.

Shafaghat, A., Salimi, F., Valiei, M., Salehzadeh, J. \& Shafaghat, M. 2012. Removal of heavy metals $\left(\mathrm{Pb}^{2+}, \mathrm{Cu}^{2+}\right.$ and $\left.\mathrm{Cr}^{3+}\right)$ from aqueous solutions using five plants materials. African Journal of Biotechnology 11(4): 852-855.

Shi, W., Shao, H., Li, H., Shao, M. \& Du, S. 2009. Progress in the remediation of hazardous heavy metal-polluted soils by natural zeolite. Journal of Hazardous Materials 170(1): 1-6.

Srivastava, V., Sarkar, A., Singh, S., Singh, P., Araujo, A.S.F. \& Singh, R.P. 2017. Agroecological responses of heavy metal pollution with special emphasis on soil health and plant performances. Frontiers in Environmental Science 5: 64-82.

Tuğ, G.N. 2006. Determination of the factors effective on zonation of halophytic vegetation of Salt Lake, Inner Anatolia, Turkey. Ankara University. PhD. Thesis (Unpublished).

Tuğ, G.N. \& Duman, F. 2010. Heavy metal accumulation in soils around Salt Lake in Turkey. Pakistan Journal of Botany 42(4): 2327-2333. 
Wuana, R.A. \& Okieimen, F.E. 2011. Heavy metals in contaminated soils: A review of sources, chemistry, risks and best available strategies for remediation. International Scholarly Research Notices 2011: 402647.

Yang, Y.Y., Jung, J.Y., Song, W.Y., Suh, H.S. \& Lee, Y. 2000. Identification of rice varieties with high tolerance or sensitivity to lead and characterization of the mechanism of tolerance. Plant Physiology 124(3): 1019-1026.

Aynur Demir*

Department of Urbanization and Environmental Problems Faculty of Economics and Administrative Sciences

Aksaray University

68100, Aksaray

Turkey

Gökçen Baysal Furtana

Department of Biology

Faculty of Science

Gazi University

06500, Ankara

Turkey
Mehtap Tekşen

Department of Biology

Faculty of Science and Letters

Aksaray University

68100, Aksaray

Turkey

Rukiye Tipirdamaz

Department of Biology

Faculty of Science

Hacettepe University

06800, Ankara

Turkey

*Corresponding author; email: aynurdemir_1@hotmail.com

Received: 14 April 2020

Accepted: 21 April 2021 